\title{
The Peripheral Giant Cell Granuloma in Edentulous Patients: Report of Three Unique Cases
}

\author{
Osman A. Etoz \\ Ahmet Emin Demirbas ${ }^{\mathrm{a}}$ \\ Mehmet Bulbul \\ Ebru Akayc
}

\begin{abstract}
The peripheral giant cell granuloma (PGCG) is a rare reactive exophytic lesion taking place on the gingiva and alveolar ridge usually as a result of local irritating factors such as trauma, tooth extraction, badly finished fillings, unstable dental prosthesis, plaque, calculus, chronic infections, and impacted food. This article presents 3 cases of PGCG that presented at the same location of the edentulous mandible of patients that using complete denture for over ten years. (Eur J Dent 2010;4:329-333)
\end{abstract}

Key words: Peripheral giant cell granuloma; Chronic irritation; Edentulous patients; Complete denture.

\section{INTRODUCTION}

Giant cell granuloma lesions (peripheral and central) are benign, non-odontogenic, moderately rare tumors of the oral cavity. They develop peripherally (within gingiva) or centrally (in bone). ${ }^{1}$ The peripheral giant cell granuloma (PGCG) is a rare reactive exophytic lesion taking place on the gingiva and alveolar ridge, also known as a giantcell epulis, giant-cell reparative granuloma, os-

\footnotetext{
a Erciyes University, Faculty of Dentistry, Department of Oral and Maxillofacial Surgery, Kayseri, Turkey.

b Gaziantep University, Faculty of Dentistry, Department of Prosthodontics, Gaziantep, Turkey. c Erciyes University, Faculty of Medicine, Department of Pathology, Kayseri Turkey.

- Corresponding author: Dr. Mehmet Bulbul Gaziantep Universitesi, Dishekimligi Fakultesi, Protetik Dis Tedavisi Anabilim Dali, Kampus, Gaziantep, Turkey. E-mail: mbulbulagantep.edu.tr
}

teoclastoma, or giant-cell hyperplasia. Etiologic factors are not known, although it is thought that it may be due to an irritant or aggressive factor such as trauma, tooth extraction, badly finished fillings, unstable dental prosthesis, plaque, calculus, chronic infections, or impacted food. ${ }^{2,3}$ Clinical appearance of PGCGs can present as polyploidy or nodular lesions, primarily bluish red with a smooth shiny or mamillated surface, stalky or sessile base, small and well demarcated. ${ }^{2,4,5}$ Pain is rare and in most cases growth of the lesion is induced by constant trauma. ${ }^{3}$ PGCGs usually originate from either the periodontal ligament or mucoperiosteum. The PGCG is located in the region of the gingiva or edentulous alveolar margins, frequently in the lower jaw. ${ }^{3}$ Histological features of PGCG reveal a non-capsulated mass of tissue containing a large number of young connective tissue cells and multinucleated giant cells. ${ }^{4} \mathrm{Hem}$ - 
orrhage, hemosiderin, inflammatory cells, and newly formed bone or calcified material may also be seen throughout the cellular connective tissue. ${ }^{5,6}$ The lesion can develop at any age, though it is more common between the fifth and sixth decades of life, and shows a slight female predilection. ${ }^{4-7}$ PGCG is a soft tissue lesion that infrequently affects the underlying bone, although the latter

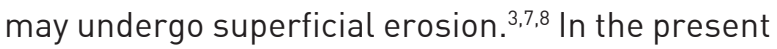
report, three cases of PGCG are presented at the same location in the mandible.

\section{CASE REPORTS}

\section{Case 1}

A 57-year-old otherwise healthy woman was referred to our clinic for a gingival mass of the lower jaw. The patient was edentulous and had been using a complete denture for more than 10 years. The tumoral lesion was located on the edentulous anterior mandible, and the patient did not know how long the lesion had been there. The patient reported neither pain nor alteration of the size of the mass. Clinical exploration revealed a red and bluish nodule, sessile lesion located on the anterior mandibular alveolar crest (Figure 1). The lesion measured $1 \times 0.5 \mathrm{~cm}$ in size and had no ulcerated surface. Radiological examination revealed no evidence of bony involvement. Treatment consisted

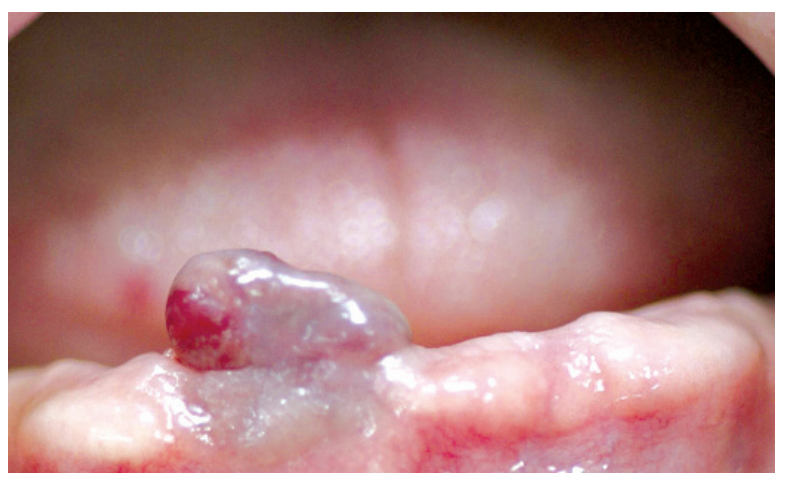

Figure 1. Clinical view of the lesion of the first patient.

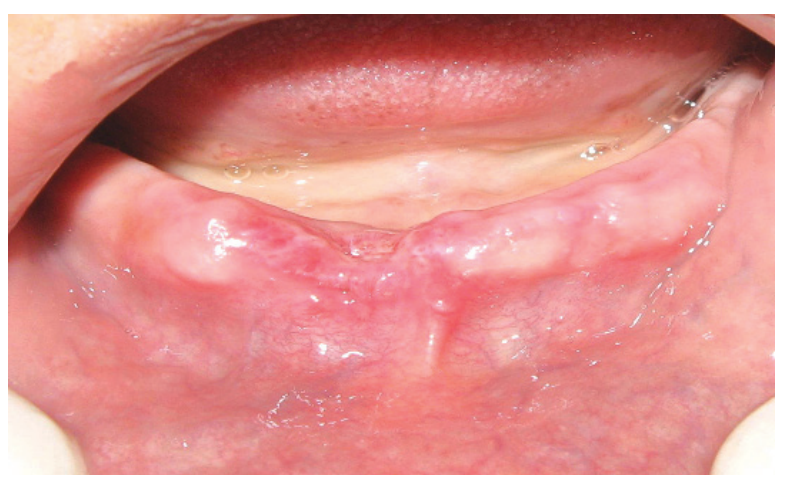

Figure 2. Clinical view of the postoperative healing of the first patient. of resection of the lesion and closure of the defect with a mucosal graft. Postoperative healing was uneventful (Figure 2) and no sign of recurrence was observed. Histopathological examination of the lesion revealed rich inflammatory cell infiltration under the epithelia, a great number of multinuclear giant cells between the inflammatory cells, and epithelioid histiocytes around the inflammatory cells. Also there were many congestive vessels, hemorrhages, and hemosiderin over the cellular connective tissue. Final diagnosis was made as PGCG.

\section{Case 2}

A 81-year-old female patient with hypertension was referred to our clinic for soft swelling on the anterior mandible. The patient was edentulous and had been using a complete denture for about 15 years. The lesion had appeared one month before. The patient reported neither pain nor alteration of the size of the mass. Clinical exploration revealed a red-bluish nodule, sessile lesion located on the anterior mandibular alveolar crest (Figure 3). The lesion measured $1 \times 0.5 \mathrm{~cm}$ in size and had no ulcerated surface. Radiological examination showed no evidence of bony involvement.

Treatment consisted of resection of the lesion and closure of the defect with a mucosal graft. Postoperative healing was uneventful (Figure 4). Histopathological examination confirmed the diagnosis of PGCG (Figure 5). Through the one-year follow-up period, there were no complaints or recurrences.

\section{Case 3}

A 53-year-old otherwise healthy male patient was edentulous and had been using a complete denture for more than 10 years. The patient reported a painless lesion at the anterior mandible

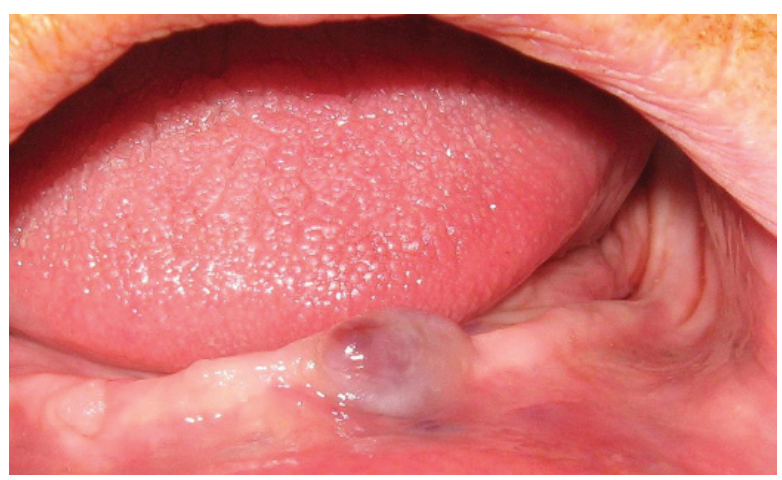

Figure 3. Clinical view of the lesion of the second patient. 
which had grown in size in the last few months. Clinical examination revealed a red-bluish nodule, sessile lesion located on the anterior mandibular alveolar crest (Figure 6). The lesion measured $1 \times 0.5 \mathrm{~cm}$ in size and had no ulcerated surface. Radiological exploration showed no evidence of bony involvement. The lesion was resected and the wound was closed with a mucosal graft. Postoperative healing was uneventful (Figure 7). Histopathological examination confirmed the diagnosis of PGCG (Figures 8 and 9). Through the one-year



Figure 4. Clinical view of the postoperative healing of the second patient.

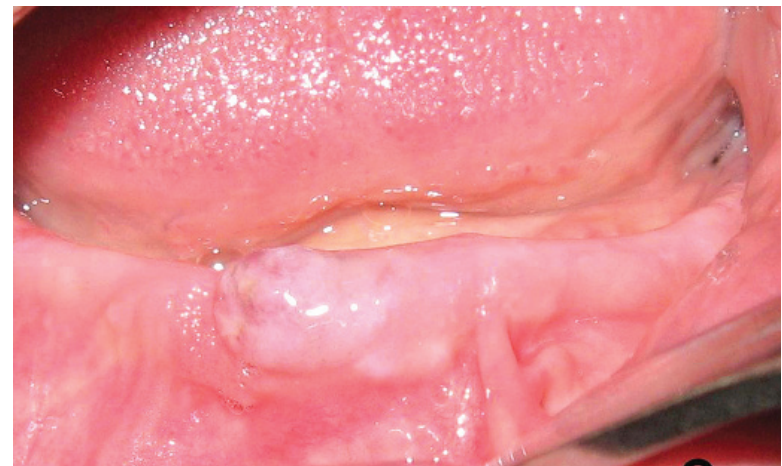

Figure 6. Clinical view of the lesion of the third patient.

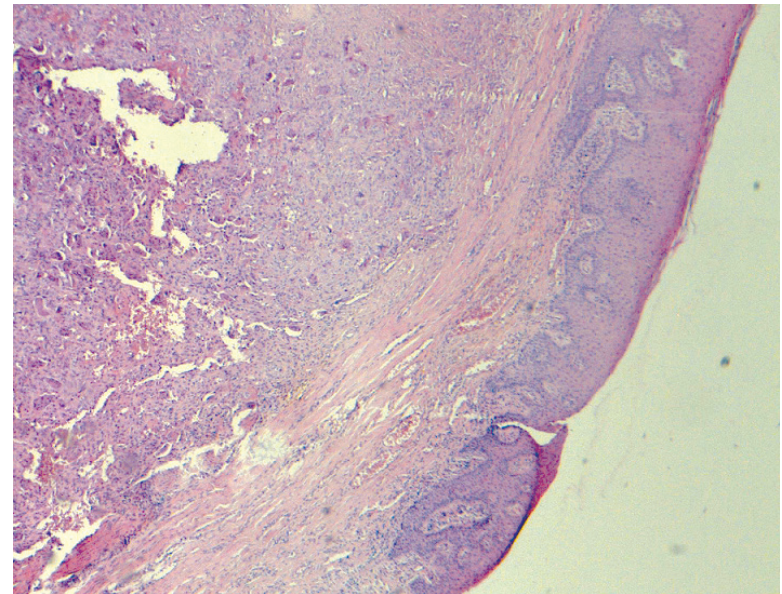

Figure 8. Histopathological view of the lesion of the third patient (hematoxylin eosin X40).

July 2010 - Vol.4 follow-up period, there were no complaints or recurrences.

\section{DISCUSSION}

Peripheral giant cell granuloma (PGCG) is a benign hyperplastic reactive lesion which is a relatively uncommon lesion of the oral mucosa. PGCG originates from the periodontal ligament or mucoperiosteum and is usually caused by local irritation or chronic trauma. The etiology of PGCG is unknown. Local irritation factors such as



Figure 5. Histopathological view of the lesion of the second patient (A- hematoxylin eosin $\mathrm{X} 40$ ).

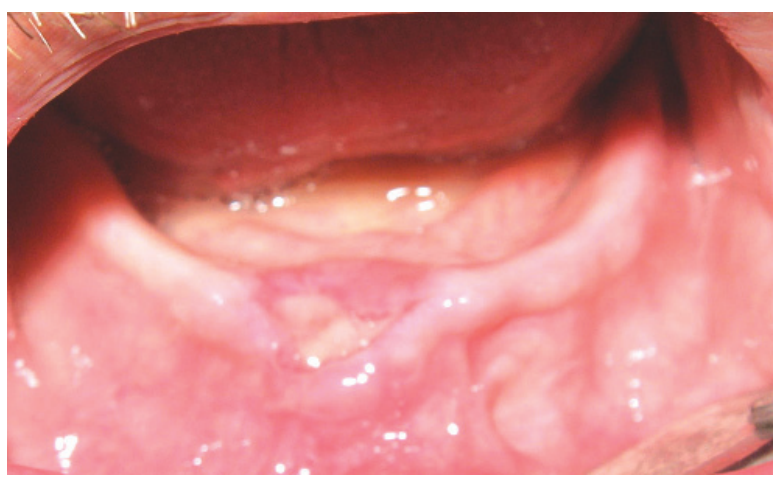

Figure 7. Clinical view of the postoperative healing of the third patient.



Figure 9. Histopathological view of the lesion of the third patient (hematoxylin eosin X200). 
poor dental restorations, unstable dental prosthesis, dental extractions, plaque and calculus accumulation, and food retention seem to play a significant role in the development of a PGCG. 2,3,5,911 Histopathologic characteristics of PGCG may be consistent with periodontal ligament or periosteum origin. ${ }^{4}$ Histologically, PGCG is identified as a non-encapsulated mass of tissue compiled of a reticular and fibrillar connective tissue stroma containing profuse young connective tissue cells of ovoid or fusiform shape, and multinucleated giant cells. ${ }^{8}$ The fibrocellular reaction is akin to that of other reactive lesions such as fibrous hyperplasia and peripheral ossifying fibroma. ${ }^{10-12}$ The calcified material or newly formed bone may also be seen all over the cellular connective tissue, and some of the lesions may be either woven bone or lamellar bone produced by the mononuclear stromal cells, which might be similar to latent proliferative osteoblasts or osteoprogenitor cells.,6,13 The microscopic appearance of PGCG is distinctive mainly due to the large number of multinucleated giant cells that are disseminated in the connective tissue stroma. ${ }^{4}$ The exact basis of the giant cells is still uncertain. Many opinions have been offered in the literature, as osteoblasts, phagocytes, endothelial cells, and spindle cells are thought to be responsible for giant cell proliferation.6,14 The widely reported discrepancy in the gender ratio may mirror the small number of cases considered in some series, but the majority of studies agree that there is a female predominance. ${ }^{15}$ In this report, two of our three patients were female. PGCG is seen in almost every decade group, but most patients were aged between four and seven decades, as reported in previous studies. ${ }^{4,5,7}$ Two of our patients were in the five-decade age cohort and one patient was in the eighth decade. The af- fected site for all patients in this report was the anterior mandible. In the literature, PGCG is more common in the lower jaw than in the upper jaw. ${ }^{4,5}$ Clinically, PGCG is a smooth brown, red, or bluish nodule, sessile or pedunculated. Radiographic examinations generally have no findings, because the lesion is a soft tissue mass. Although the etiology of PGCG is unclear, in the present report the etiologic factor is thought to be chronic trauma, because of unstable prosthesis. Our three patients have used complete dentures for numerous years. PGCGs generally develop either in the gingival tissue or in the alveolar processes of the incisor and canine region. ${ }^{3}$ Of our three cases, all were located in the edentulous alveolar margins of the anterior mandibular region. Lesion size differs from 0.5 to $1.5 \mathrm{~cm}$ in diameter, although there have been $5 \mathrm{~cm}$ size cases in the literature, in which factors such as poor oral hygiene or xerostomia seem to play an important role in lesion growth. ${ }^{4}$ None of our cases exceeded $2 \mathrm{~cm}$ in size.

In the present report, all three cases have had long-term use of complete dentures that might be thought of as having the possible effect of unstable dental prostheses on PGCGs etiology. The most preferred occlusion type for complete dentures is bilateral balanced occlusion (BBO). In $\mathrm{BBO}$, the anterior teeth do not make contact during functional movements (Figure 10). ${ }^{16}$ Over time, as a result of posterior denture erosion, anterior teeth may contact. ${ }^{17}$ These contacts may cause resorption on residual ridges and so soft tissues can lose bone support and, after all these changes, increased forces may create irritation on these areas. ${ }^{16,18,19}$ This may be an irritant factor for PGCG development. Edentulous patients wearing complete dentures should be followed up at one-year intervals and should be considered for implant-

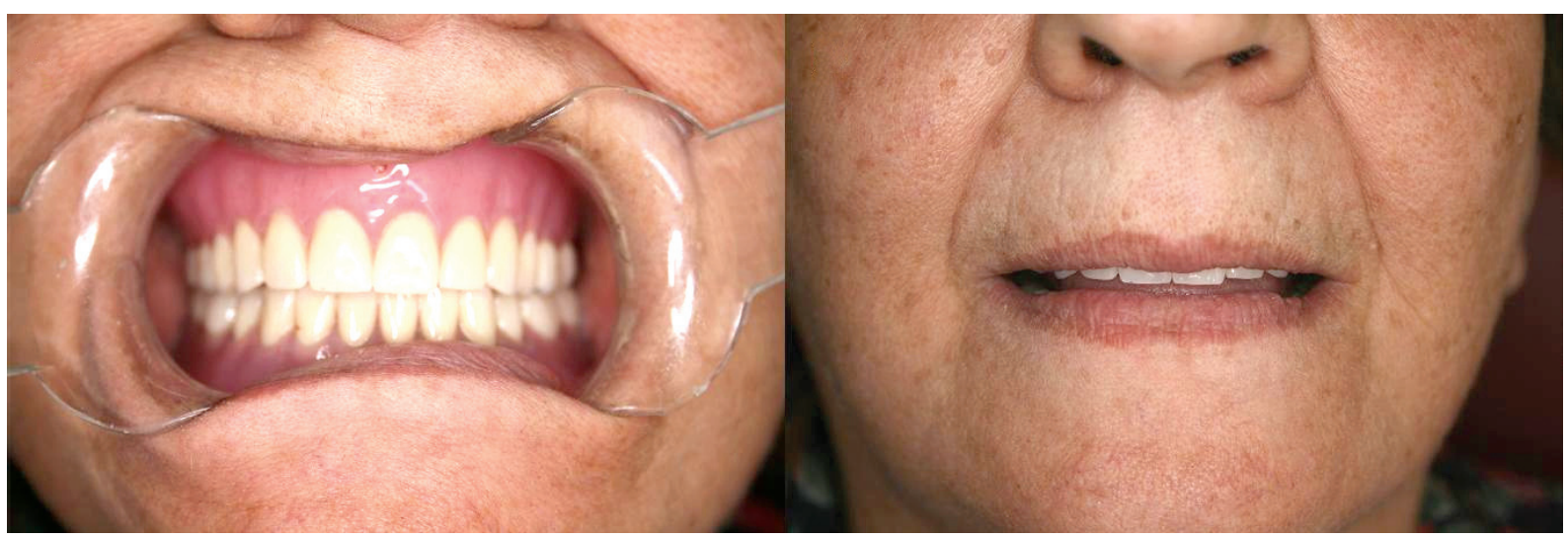

Figure 10. Clinical view of the post prothetic treatment of first patient. 
supported dentures to prevent soft tissue trauma. Complete dentures should be re-fabricated every five years even for asymptomatic cases in order to avoid possible development of reactive lesions such as PGCG.

\section{REFERENCES}

1. Duarte-Ruiz B, Riba-García FA, Navarro-Cuéllar C, Bucci T, Cuesta-Gil M, Navarro-Vila C. Reparative giant cell granuloma in a pediatric patient. Med Oral Patol Oral Cir Bucal 2007;12:E331-E335.

2. Gándara JM, Pacheco JL, Gándara P, Blanco A, García A, Madriñán P, Somoza M.Granuloma periférico de células gigantes. Revisión de 13 casos clínicos. Medicina Oral 2002; 7:254-259

3. Chaparro-Avendaño Av, Berini-Aytés L, Gay Escoda C. Peripheral giant cell granuloma. A report of five cases and review of the literature. Med Oral Patol Oral Cir Bucal 2005; 10:48-57.

4. Lipa Bodner, Mauricio Peist, Albert Gatot, Dan M. Fliss. Growth potential of peripheral giant cell granuloma. Oral Surg Oral Med Oral Pathol Oral Radiol Endod 1997;83:548551.

5. Katsikeris N, Kakarantza-Angelopoulou E, Angelopoulos AP. Peripheral giant cell granuloma: clinicopathologic study of 224 new cases and review of 956 reported cases. Int J Oral Maxillofac Surg 1988;17:94-99.

6. Shafer WG, Hine MK, Levy BM. A textbook of oral pathol 4th ed. Philadelphia: WB Saunders 1983:144-146.

7. Motamedi MH, Eshghyar N, Jafari SM, Lassemi E, Navi F, Abbas FM, Khalifeh S, Eshkevari PS. Peripheral and central giant cell granulomas of the jaws: A demographic study. Oral Surg Oral Med Oral Pathol Oral Radiol Endod 2007;103:e39-e43

8. Flaitz CM. Peripheral giant cell granuloma: a potentially aggressive lesion in children. Pediatr Dent 2000;22:232233.

9. Grand E, Burgener E, Samson J, Lombardi T. Post-traumatic development of a peripheral giant cell granuloma in a child. Dental Traumatol 2008;24:124-126.

10. Kfir Y, Buchner A, Hansen LS. Reactive lesions of the gingiva. A clinicopathological study of 741 cases. J Periodontol 1980;51:655-661.

11. Anneroth G, Sigurdson A. Hyperplastic lesions of the gingiva and alveolar mucosa. A study of 175 cases. Acta Odontol Scand 1983;1:75-86.

12. Bodner L, Dayan D. Growth potential of peripheral ossifying fibroma. J Clin Periodontol 1987; 14:551-554.

13. Dayan D, Buchner A, Spirer S. Bone formation in peripheral giant cell granuloma. J Periodontol 1990;61:444-446.
14. Lucas RB. Pathology of tumors of the oral tissues. 4th ed. London: Churchill Livingstone, 1984:259-272.

15. AJ Mighell, PA Robinson, WJ Hume. Peripheral giant cell granuloma: a clinical study of 77 cases from 62 patients, and literature review. Oral Diseases 1995:1;12-19

16. Aeron $H$, Fenton A. Selecting and arranging prosthetic teeth and occlusion for the edentulous patient. In: George A. Zarb, Charles L. Bolender (eds). Prosthodontic treatment for edentulous patients. Mosby. St. Louis, MO, USA. 2004:298-328.

17. Ejving Budtz-Jorgensen. Prosthodontics for the elderly. Quintessence Publishing co. Illinois, USA 1999:203-228.

18. Hickey JC. Zarb GA. Boucher's prosthodontic treatment for edentulous patients. 8th ed. St Louis: CV Mosby; 1980:455479 .

19. Ansari IH. Simplified clinical remount for complete dentures. J Prosthet Dent 1996:76;321-324. 